\title{
THE QUALITY OF ACCOUNTING INFORMATION SYSTEM: A CASE OF REGIONAL PUBLIC HOSPITAL MANOKWARI
}

\author{
Mona Permatasari Mokodompit \\ Fakultas Ekonomi dan Bisnis, Universitas Papua \\ mmokodompit@gmail.com \\ Anik Wuriasih \\ Fakultas Ekonomi dan Bisnis, Universitas Papua \\ akoeanik@gmail.com
}

\begin{abstract}
This study aims to examine the influence of several factors (user involvement in the development process of accounting information system, training and education, and top management support) on the quality of accounting information system at the Manokwari Regional Public Hospital. We distribute our questionnaire and conduct the interviews to 35 accounting information system users at this hospital to generate our research data. Our findings indicate that only top management support significantly affects the quality of accounting information system. Practically, this study contributes to address the issue of the quality of accounting information system at the Manokwari Regional Public Hospital.
\end{abstract}

Keywords: quality of accounting information system, user involvement, training and education, top management support.

\begin{abstract}
ABSTRAK
Penelitian ini mengkaji pengaruh beberapa faktor (keterlibatan pengguna dalam proses pengembangan sistem informasi akuntansi, pelatihan dan pendidikan, dan dukungan manajemen puncak) terhadap kualitas sistem informasi akuntansi di Rumah Sakit Umum Daerah (RSUD) Manokwari. Data penelitian dikumpulkan dengan menyebarkan kuesioner dan melakukan wawancara kepada 35 pengguna sistem informasi akuntansi RSUD Manokwari. Hasil dari penelitian ini menunjukkan bahwa dari ketiga faktor yang diteliti hanya faktor dukungan manajemen puncak yang memiliki pengaruh terhadap kualitas sistem informasi akuntansi. Sedangkan untuk keterlibatan pengguna dan pelatihan dan pendidikan tidak memiliki pengaruh terhadap sistem informasi akuntansi. Hasil penelitian ini dapat digunakan untuk memecahkan masalah terkait kualitas kualitas sistem informasi akuntansi pada RSUD Manokwari.
\end{abstract}

Kata Kunci: kualitas sistem informasi akuntansi, keterlibatan pengguna, pelatihan dan pendidikan, dukungan manajemen puncak. 


\section{INTRODUCTION}

The development of technology nowadays provides great impact on human life in various aspects of organization activities, including organization such as the hospital. As a service organization, the hospital has a broad range of functions including services, education, and research with various level and types of activities. To be able to perform those duties, professional human resources as well as a relevant and accurate information system is needed.

However, a lot of data in a hospital, including financial and accounting data, is being stored, processed and shared each day. Without using accounting information system, it will require the longer time to process the data, and there is also a possibility of miscalculation of the data. Thus, information given becomes less relevant and less accurate to users to be used in decision-making. Therefore, those data should be managed with the use of accounting information system to produce useful information to users and also to achieve competitive advantage.

Regional Public Hospital Manokwari (RSUD), as one health care institution, has implemented accounting information system to manage its data, namely: (1) Hospital Management Information System (SIMRS), a system that support the process of management functions and decision-making in providing hospital's health services; (2) Regional Financial Management Information System (SIMDA), a developed software that help to manage finances efficiently and effectively based on legislation; and (3) Indonesia Case-Base Groups (INA-CBGs), an application used to submit hospital, health centers and other Health Care Providers (PPK) claims for the poor in Indonesia.

However, the quality of accounting information system can be influenced by several factors. Early studies on the factors affecting the quality of accounting information systems such as Chomasatu (2014) and Rivaningrum (2015), gave evidence that the quality of accounting information system is influenced by user involved in the development process of accounting information system, training and education, and top management support. Contradictory, studies by Widyaningrum (2015) stated that there is no influence of users involvement in the development process of accounting information system, training and education, and top management support on the quality of accounting information system. Studies conducted by Almilia and Briliantien (2007) found that user involvement in the development process of accounting information system also do not influence the quality of accounting information system.

The mixed findings on the factors influencing the quality of accounting information system are the primary motivation for this study. However, the difference between this study and previous study is the selected research object. The hospital was chosen as a research object in this study by bearing in mind the important role of hospitals in the society and also the pressure faced by hospitals from different 
stakeholders to become more cost efficient and to provide more quality services. The accounting information system helps hospitals for improving the quality of their financial and administrative performance.

Therefore, this study is conducted to provide empirical evidence about the influence of user involvement in the development process of accounting information system, training and education, and top management support on the quality of accounting information system at Regional Public Hospital Manokwari. Thus, the first objectives of this study are to analyze whether user involvement in the development process of accounting information system has influences on the quality of accounting information system. The secondary objectives were to examine that training and education influence on the quality of accounting information system. The research also investigates how top management supports impact on the quality of accounting information system. The result of this study can be used as a consideration material to solve problems related to the quality of accounting information system at Regional Public Hospital Manokwari.

\section{LITERATURE REVIEW}

\section{Quality Accounting Information System}

Definition of Accounting Information System as said by Romney and Steinbart (2006) is a system that collects, records, stores and processes data to generate the information for decision makers. Jogiyanto (2005) states that accounting information system can changes business transactions data into useful financial information for the user. According to Almilia and Briliantien (2007), the success of accounting information system can be measured by the quality of the system, since the quality of the system will determine the user's satisfaction. Rivaningrum (2015) state that the quality of accounting information system demonstrates the effectiveness, which can be measured by user's satisfaction. A high quality of accounting information system is when the system can meet the user's need (Srimindarti and Puspitasari 2012). The indicators used in this study for the quality of accounting information system is user's satisfaction. It indicates whether the user is satisfied and believed that the system could meet their needs. The variable used an instrument developed by Doll and Torkzadeh (1988).

\section{User Involvement in the Development of the Accounting Information System}

User involvement is involvement in the development of the system by member of the organization or member of the target user group (Choe 1996). User involvement in the development of accounting information system can be interpreted as a form of mental and emotional involvement of employees that activate them to give a contribution and have the responsibility in the development of accounting information system to achieve goals. The quality of accounting information is expected to increase 
when users have the opportunity to give opinions and suggestions related to the development of accounting information system (Puspitasari 2007).

Any advanced information system needs to recognize the users so it will be compatible to use. According to Soegiharto (2001), the user involvement in the development of accounting information system can improve the quality of accounting information system by (1) giving a more accurate and complete research to the terms of user information, (2) providing expertise about the organization for which the system is supported, (3) avoiding the unaccepted construction features and (4) improving the understanding of the information system users. User involvement can be measured by scaling participation of the user in the whole process of implementation of the system (Soegiharto 2001). Thus, the indicator used in this study for user involvement in the development of the accounting information system on the quality of the accounting information system is the user's participation in the whole process of the accounting information system implementation. This variable is measured with an instrument used by Soegiharto (2001).

\section{Training and Education}

Training and education for accounting information system users are defined as a formal venture for the purpose of knowledge transfer of information system, which includes information system concepts, technical skills, organizational capabilities and knowledge of specific information system products (Choe 1996). Gibb (1997) state that training is the acquisition of skills, knowledge, habits and attitudes needed to perform the different tasks involved in the administration of a business. The training program of the accounting information system used in an organization can improve the system that already exists, either for the system development or decisions making (Rivaningrum 2015). Furthermore, system users who are higher educated and have accounting and information system, and computer-based accounting as their educational background certainly knows more about a good accounting information system (Koeswoyo 2006).

According to Komara (2005), an organization in the development of accounting information system should conduct training and education for the users of accounting information system. Soegiharto (2001) state that the purpose of training and education for the users of accounting information system is to improve the user's ability and understanding of the system used. Moreover, Almilia and Brilliantien (2007) state that training and education for the users of accounting information system will improve the quality of the accounting information system. The indicator that can be used to measure training and education on the quality of accounting information system is to detect whether training and education is provided for the users of the accounting information system (Soegiharto 2001). Therefore, the indicator used in this study for training and education on the quality of accounting information system is by detecting whether training and education are provided for the users of the accounting information system. This variable is measured with an instrument used by Soegiharto (2001). 


\section{Top Management Support}

Top management support is the understanding of top managers about computer systems and the level of interest, support, and knowledge about information systems or computerization (Halimatusadiah et al., 2015). The level of support provided by the top management for organization's information system is a very important factor in determining the success of all activities related to information systems (Komara 2005). Top management is the central point of an information system, where the managers use information system in making type of decisions to achieve certain goals (Rivaningrum 2015).

According to Jen (2002), the success of an accounting information system cannot be separated from the support of top management. The greater the support is given by top management will improve the quality of accounting information system, since there is a definite link between top management support in the development process and operation of accounting information system with the quality of the accounting information system. Furthermore, Soegiharto (2001) used the involvement of top management in planning and control of accounting information system as the indicator to measure top management support on the quality of the accounting information system. Therefore, the indicator used in this study for top management support on the quality of accounting information system is the involvement of top management in planning and control of accounting information system. This variable is measured with an instrument developed by Choe (1996).

\section{Theoretical Framework}

The application of a system within a company confronts two things, whether the implementation of the system is successful or unsuccessful (Komara 2005). Handayani (2007) explains that information system plays a role in the accounting field within the Statement of Financial Accounting Concept No. 2 Financial Accounting Standards Board. Nowadays, health institutions such as hospitals also require the use of accounting information systems to manage its financial and accounting data to support the main activities of the hospital. It can also be used for of decision-making in managing a business (Rivaningrum 2015).

There are several factors influencing the quality of accounting information systems including the user involvement in the development of the accounting information system, training and education, and top management support (Rivaningrum 2015; Immelda 2015). Jen (2002) state that user involvement in the development of accounting system information has the positive influence on the quality of accounting information system. The more users are involved, the more they are given the opportunity to give opinions and suggestions in the development process of the system and it will increase the quality of the accounting information system (Rivaningrum 2015). Abhimantara and Suryana (2016) also concluded that user 
involvement in the development of accounting system information is one of the factors influencing the quality of accounting information system.

Other researchers such as Holmes and Nicholls (1988) found that formal training has influence on the preparation of accounting information. Further, Respati et al. (2013); Ane and Anggraini (2012) concluded in their studies that training and education has an influence on the quality of accounting information system. Similar with the user's involvement in the development of accounting information system, training and education for system's users can also increase the system's quality since it increases their understanding and ability to use the system (Rivaningrum 2015).

Moreover, top management support for system development also contributed to measure the quality of the system since they also use the system for making decisions (Rivaningrum 2015). Empirical studies were done by DeLone (1988) and Choe (1996) concluded that top management support have positive influence on the quality of accounting information system. Similarly, study results by Jen (2002) also state that top management support have positive influence on the quality of accounting information system, where the greater the support the further the improvement of accounting information system would be.

This study is aimed to determine the casual relationships between variables through hypothesis testing present as follows:

\section{The relation between user involvement in the development of accounting information system and the quality of accounting information system}

An organization in presenting its financial report should be able to ensure that the information provided through the report is accurate in order to facilitate user's in decision-making. Thus, the accounting information system is used and the need of user involvement in the development of accounting information system will determine the quality of the system. Users of the system are considered as people who understand the system including the constraints of the system, both technical and non-technical. Therefore, increasing user involvement will improve the quality of accounting information system. This is supported by research conducted by Jen (2002) which states that the user involvement in the development of the system will improve the quality of the system due to the positive relationship between user involvement in the development of the system with the quality of accounting information system. Based on the description above they following hypothesis is developed:

H1: User involvement in the development of the accounting information system has positive influence on the quality of accounting information system 


\section{The relation between training and education with the quality of accounting information system}

Educational program and training of the accounting information system used in the organization can improve the user's ability and understanding of the system. Thus, the user can identify the limitation or constraints that exist in the system and this information can be used as a consideration to improve the quality of the system. A study by Jen (2002) states that the quality of accounting information system will increase if educational program and training of the system are introduced to users. Based on the description above they following hypothesis is developed:

H2: Training and education has positive influence on the quality of accounting information system.

\section{The relation between top management support and the quality of accounting information system}

The top management of an organization is the most influential party in terms of decision-making. Therefore, top management support has an important role in the phase of accounting information system development and its success. Moreover, the top management needs to socialize the system used to motivate users to participate in the system development (Soegiharto 2001). According to Jen (2002), there is a definite relation between top management support in the developing and operating an accounting information system with the quality of accounting information system. Thus, greater top management support will increase the quality of accounting information system. Based on the description above they following hypothesis is developed:

H3: Top management support has positive influence on the quality of accounting information system.

Based on the previous explanations, the theoretical framework of this study is as follows: 


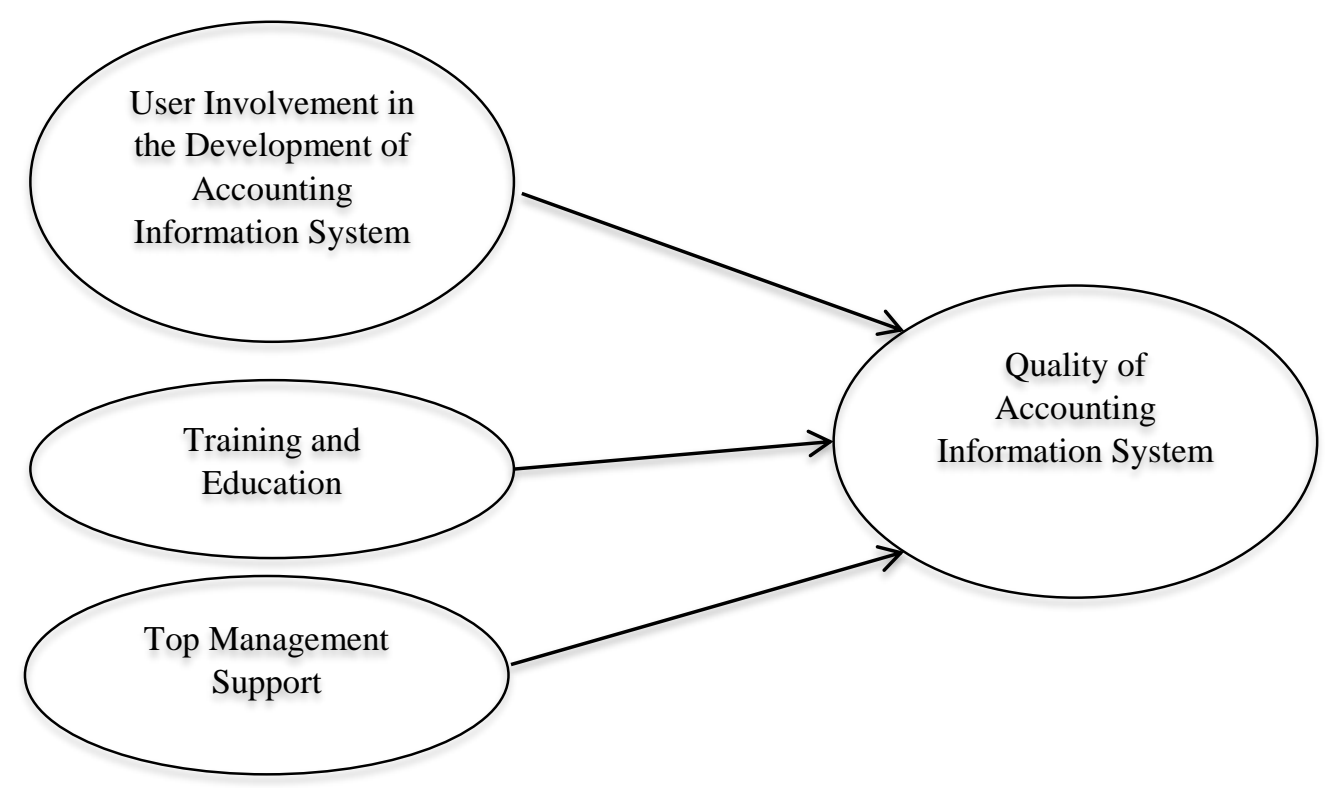

Figure 1

Theoretical Framework of the Study

\section{RESEARCH METHOD}

\section{Sample and Research Data}

The research samples are 35 users of accounting information system in Regional Public Hospital Manokwari. Regional Public Hospital Manokwari is chosen as the research object in this study due to its importance in the society and its role to provide health services. Furthermore, as the only public hospital in Manokwari that publicly funded and not for profit it cannot refuse anyone, therefore often it is overloaded with patients. Thus, the accounting information plays an important role in the process of managing the hospital's activity.

The research data of this study are collected using a closed questionnaire and interview. The questionnaire questions have been adopted from Rivaningrum (2015) with five Likert's scale to score the responses.

\section{Operational Definition and Variable Measurement}

This study aims to examine the influence of several factors (user involvement in the development process of accounting information system, training and education, and top management support) on the quality of accounting information system at General Public Hospital Manokwari. Operational definition and variable measurement are presented in the Table 1 below. 
Table 1

Operational Definition and Variable Measurement

\begin{tabular}{|c|c|c|}
\hline Variable & Operational Definition & Indicator \\
\hline $\begin{array}{l}\text { Quality of Accounting } \\
\text { information System }\end{array}$ & $\begin{array}{l}\text { Satisfaction and trust of the users in the } \\
\text { information provided by the system to } \\
\text { meet their needs (Rivningrum } 2015 \text { ) }\end{array}$ & $\begin{array}{l}\text { User satisfaction of } \\
\text { accounting information }\end{array}$ \\
\hline User Involvement in the & Involvement of the users as members of & User participation in the \\
\hline $\begin{array}{l}\text { Development of } \\
\text { Accounting Information }\end{array}$ & $\begin{array}{l}\text { the organization in the developing } \\
\text { process of information system (Choe }\end{array}$ & $\begin{array}{l}\text { implementation process of } \\
\text { accounting information }\end{array}$ \\
\hline $\begin{array}{l}\text { System (Independent } \\
\text { Variable) }\end{array}$ & & \\
\hline $\begin{array}{l}\text { Education and Training } \\
\text { (Independent Variable) }\end{array}$ & $\begin{array}{l}\text { Formal effort through education and } \\
\text { training programs in order to transfer } \\
\text { knowledge of information system (Choe } \\
\text { 1996) }\end{array}$ & $\begin{array}{l}\text { The existence of education } \\
\text { and training program on } \\
\text { how to use the system and } \\
\text { the benefits obtained }\end{array}$ \\
\hline $\begin{array}{l}\text { Management } \\
\text { (Independent }\end{array}$ & $\begin{array}{l}\text { Top management understand about the } \\
\text { computer system and level of interest, as } \\
\text { well as giving support and having } \\
\text { knowledge about the information } \\
\text { system (Kim et al., 1998) }\end{array}$ & $\begin{array}{l}\text { The involvement of top } \\
\text { management in planning } \\
\text { and control of accounting } \\
\text { information system }\end{array}$ \\
\hline
\end{tabular}

\section{Hypothesis Testing}

The data in this study are analyzed by testing the hypothesis (F-test, t-test and coefficient determination test). F-test is also known as the feasibility test, where it aims to test whether the estimated model used is eligible (reliable) to explain the influence of independent variables on the dependent variable. The estimated model is feasible when the value of $\mathrm{F}$ probability is smaller than 0.05 . Meanwhile, the $\mathrm{t}$-test is performed to test the significance level and determine whether the hypothesis is rejected or accepted. With the error rate of 5 percent, the hypothesis is accepted if the significant coefficient value is less than 0.05 . As for the coefficient determination aims to indicate the proportion of the independent variable in explaining the dependent variable.

This study used multiple linear regression analysis in determining the influence of user involvement in the development of accounting information system, training and education, and top management support on the quality of accounting information system.

\section{RESULTS}

The questionnaires used as a data collection instrument are distributed to all 35 users of accounting information system in Regional Public Hospital Manokwari, and all 35 questionnaires are returned. Therefore, the response rate is 100 percent. Approximately, more than half of the respondent (68.57 percent) were between 21-30 years old followed by 25.71 percent who were between 31-40 years old, 2.86 percent who were between $41-50$ years old and 2.86 percent who $>50$ years old. The majority of the respondents (54.29 percent) had a diploma certificate, 37.14 percent who had an undergraduate certificate and 8.57 percent had a high school certificate. The 
description of respondents can be seen in Figure 2. As for the statistic descriptive of this research is presented in Table 2.
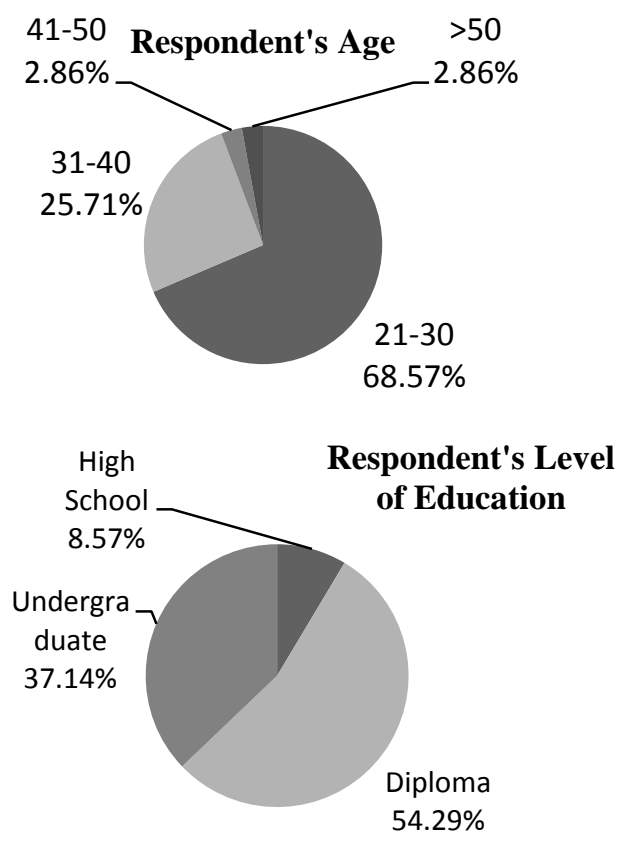

Figure 2

Description of Respondents

Table 2

Statistic Descriptive

\begin{tabular}{lccc}
\hline \multicolumn{1}{c}{ Variabel } & Max. & Mean & $\begin{array}{c}\text { Std. } \\
\text { Deviation }\end{array}$ \\
\hline $\begin{array}{l}\text { User Involvement in the } \\
\text { Development of } \\
\text { Accounting Information }\end{array}$ & 14 & 10.09 & 2.48 \\
$\begin{array}{l}\text { System (UI) } \\
\text { Training and Education } \\
\text { (TE) }\end{array}$ & 14 & 8.46 & 3.1 \\
$\begin{array}{l}\text { Top Management } \\
\text { Support (TMS) } \\
\text { Quality of Accounting } \\
\begin{array}{l}\text { Information System } \\
\text { (QAIS) }\end{array}\end{array}$ 70 & 25.06 & 6.121 \\
\hline Source: calculated primary data & 52.77 & 11.13 \\
\hline
\end{tabular}

Source: calculated primary data

\section{Validity and Reliability Test}

Based on the results of data processing presented in Table 3, it is known that the instrument used in this study is valid and reliable with value significance observation of $\alpha$ is smaller than 5 percent and the value of Cronbach's alpha is above 0.60 . 
Table 3

The Result of Validity and Reliability Test

Dependent Variable

\begin{tabular}{|c|c|c|c|}
\hline Indicator & $\begin{array}{l}\text { Correlation } \\
\text { Value }\end{array}$ & Sig & $\begin{array}{l}\text { Cronbach's } \\
\text { Alpha }\end{array}$ \\
\hline The Quality of Accounting Information System: & & & 0.92 \\
\hline The system is able to help the department to function well & 0.88 & 0.000 & \\
\hline The system is an important success factor in my department & 0.86 & 0.000 & \\
\hline The system is able to increase my work satisfaction & 0.84 & 0.000 & \\
\hline The system always give information that the department needs & 0.8 & 0.000 & \\
\hline I like to use the system provided & 0.83 & 0.000 & \\
\hline $\begin{array}{l}\text { My department is able to finish the work efficiently and } \\
\text { effectively by using the system }\end{array}$ & 0.9 & 0.000 & \\
\hline $\begin{array}{l}\text { The system gives contribution in order to achieve organization's } \\
\text { goals and missions }\end{array}$ & 0.74 & 0.000 & \\
\hline Most department staff is interested to use the system & 0.74 & 0.000 & \\
\hline System is supported with accurate and reliable information & 0.58 & 0.000 & \\
\hline $\begin{array}{l}\text { The system can easily adjust with new conditions according to the } \\
\text { need of information development either now or in the future }\end{array}$ & 0.58 & 0.000 & \\
\hline \multicolumn{4}{|l|}{ Independent Variables } \\
\hline Indicator & $\begin{array}{l}\text { Correlation } \\
\text { Value }\end{array}$ & Sig & $\begin{array}{l}\text { Cronbach's } \\
\text { Alpha }\end{array}$ \\
\hline $\begin{array}{l}\text { User Involvement in the Development of Accounting } \\
\text { Information System: }\end{array}$ & & & 0.90 \\
\hline My level of participation in the system development & 0.95 & 0.000 & \\
\hline My level of influence in the system development & 0.96 & 0.000 & \\
\hline Training and Education: & & 0.000 & 0.72 \\
\hline $\begin{array}{l}\text { The company has training and education program about how to } \\
\text { use the system }\end{array}$ & 0.88 & 0.000 & \\
\hline $\begin{array}{l}\text { There is an advantage that I get from the training and education } \\
\text { program }\end{array}$ & 0.89 & 0.000 & \\
\hline Top Management Support: & & & 0.92 \\
\hline Top management is good at using computer & 0.74 & 0.000 & \\
\hline $\begin{array}{l}\text { Top management has high expectation on the use of the } \\
\text { information system }\end{array}$ & 0.87 & 0.000 & \\
\hline $\begin{array}{l}\text { Top management is actively involved in planning the information } \\
\text { system operation }\end{array}$ & 0.9 & 0.000 & \\
\hline $\begin{array}{l}\text { The top management gives serious attention towards the quality of } \\
\text { information system }\end{array}$ & 0.92 & 0.000 & \\
\hline $\begin{array}{l}\text { Top management is highly satisfied with user rating of information } \\
\text { system from the user departments }\end{array}$ & 0.9 & 0.000 & \\
\hline
\end{tabular}

Source: calculated primary data

\section{Multiple Linear Regression Analysis}

Using SPSS for Windows, multiple linear regression analysis is chosen to determine the degree or strength of the relationship between the dependent variable and the independent variables. The following tests are used to analyze the research data: 


\section{F-Test Result}

The feasible test of the model (goodness of fit) in this study is presented in table 4. It shows that the calculated value of $F$ is 12,489 with a significant probability of 0.000 which is smaller than 0.05 . Therefore, the estimated regression model used in this study is feasible or in other words can be used to predict the quality of accounting information system at Regional Public Hospital Manokwari.

Table 4

Hypothesis Test Result

\begin{tabular}{lcccc}
\hline \multicolumn{1}{c}{ Model } & & t & \multicolumn{1}{c}{ Sig. } & Result \\
\hline $\begin{array}{l}\text { (Constant) } \\
\text { User Involvement in the }\end{array}$ & 2.36 & 0.03 & \\
$\begin{array}{l}\text { Development of Accounting } \\
\text { Information System (UI) }\end{array}$ & 0.27 & 0.79 & Reject H1 \\
$\begin{array}{l}\text { Training and Education (TE) } \\
\text { Top Management Support }\end{array}$ & & & & \\
(TMS) & & 0.67 & 0.5 & Reject H2 \\
F-Test & 12.489 & & 0.000 & Accept H3 \\
Adjusted R Square & 0.503 & & & Feasible \\
\hline Source: calculated primary data & & & &
\end{tabular}

\section{T-Test}

The T-test is performed to test the significant level and determine whether the hypothesis is rejected or accepted. Based on the calculation using SPSS for Windows, the result can be seen in Table 4 . With the error rate of 5 percent, the significance coefficient of user involvement is 0.79 more than 0.05 . Therefore $\mathrm{H} 1$ is rejected, which means user involvement in the development of accounting information system has no influence on the quality of accounting information system. Similarly, with education and training do not have the influence on the quality of accounting information system. This can bee is seen that the value of significant coefficient is 0.51 more than 0.05 . Thus, $\mathrm{H} 2$ is rejected. While the value of significance coefficient of top management support is 0.000 less than 0.05 . It indicates that $\mathrm{H} 3$ is accepted, which means top management support have positive influence on the quality of accounting information system.

\section{Coefficient Determination}

Based on the result in Table 4, it is shown that the influence of user involvement in the development of accounting information system, training and education, and top management support on the quality of accounting information system in Regional Public Hospital Manokwari is at 50.3 percent and the remaining 49.4 percent is influenced by other factors that are not examined. 


\section{DICUSSIONS}

The result of this study found that user involvement in the development of accounting information system has no influence on the quality of accounting information system (H1 is rejected) since the value of significance coefficient of user involvement is 0.789 which is more than 0.05 . This result contradicts the research finding conducted by Jen (2002), which states there is a positive relationship between users involvement in the development of the system with the quality of accounting information system. This is due to the lack of user involved in the development of the system at Regional Public Hospital Manokwari. Users of the system are considered as people who understand the system including the constraints of the system. Therefore, when users have given less opportunity to give opinions and suggestions related to the development of accounting information system then the quality of the system is not likely to increase. However, this finding support previous study conducted by Widyaningrum (2015) that state the user involvement in the development of accounting information system have no influence on the quality of accounting information system.

Similarly with training and education, the data analysis shows that training and education have no influence on the quality of accounting information system ( $\mathrm{H} 2$ is rejected). This is because the value of significance coefficient of training and education is 0.505 , which is more than 0.05. This finding contradicts the research finding conducted by Almilia and Brilliantien (2007), which states that training and education for the users of accounting information system will improve the quality of the accounting information system. However, the research finding is consistent with a study result of Widyaningrum (2015) that also found the quality of accounting information system is not influenced by training and education. This is due to the lack of training and education provided to users of the system at Regional Public Hospital Manokwari. Soegiharto (2001) state that the purpose of training and education for the users of accounting information system is to improve the user's ability and understanding of the system used. Thus, the user can identify the limitation or constraints that exist in the system and this information can be used as a consideration to improve the quality of the system, either for the system development or decisions making. Therefore, when there is lack of training and education provided to users then the quality of the system at Regional Public Hospital Manokwari is not likely to improve.

However, the top management support has an influence on the quality of accounting information system based on the study result, with the value of significance coefficient of 0.000, which is less than 0.05. This result consistent with Jen (2002), and it is because the top management has more understanding of information system and also participates in the development of the system. Top management at Regional Public Hospital Manokwari is the central point of the information system, where the managers use information system in making a variety of decisions to achieve certain 
goals. Therefore, there is a definite link between top management support in the development process and operation of accounting information system with the quality of the accounting information system. Where the greater the support is given by top management, the more likely the quality of accounting information system will improve.

\section{CONCLUSION, LIMITATION AND RECOMMENDATION}

The study focuses on the perception of the users system of Regional Public Hospital Manokwari about factors that influence the quality of accounting information system. Based on the statistical result, it is known that $\mathrm{H} 1$ and $\mathrm{H} 2$ is rejected meaning that user involvement in the development of accounting information system and training and education have no influence on the quality of accounting information system. Meanwhile, H3 is accepted meaning that top management support have influence on the quality of accounting information system.

This study was limited to system users of Regional Public Hospital Manokwari. Further, this study only examined the influence of three factors (user involvement in the development of accounting information system, training and education, and top management support) on the quality of accounting information system. Therefore, future research can extend the proposed factors.

However, the empirical evidence result in this study can be used to solve problems that occur on the quality of accounting information system. The study recommends that the quality of accounting information system can be improved through involving users more in the development of the system so they have the opportunity to contribute and also have the responsibility in the development of accounting information system in order to achieve organization's goals. Training and education about how to use the system also need to be provided to the system users in order to improve their ability and understanding of the system used. Thus, the user can identify the limitation or constraints that exist in the system and this information can be used as a consideration to improve the quality of the system.

\section{REFERENCES}

Abhimantara, W., and I. K. Suryana. 2016. "Analisis faktor-faktor yang mempengaruhi kinerja sistem informasi akuntansi”. E-Jurnal Akuntansi Universitas Udayana 14(3): 1782-1809.

Ane, L., and P. N. Anggraini. 2012. "Faktor-faktor yang mempengaruhi kinerja sistem informasi akuntansi di lingkungan pemerintah daerah Serdang Bedagai". Jurnal Telaah Akuntansi 14(2): 16-30. 
Almilia, L. S., and I. Briliantien. 2007. "Faktor-faktor yang mempengaruhi kinerja sistem informasi akuntansi pada bank umum pemerintah di wilayah Surabaya dan Sidoarjo". Jurnal STIE Perbanas Surabaya.

Choe, J. M. 1996. "The relationships among performance of accounting information systems, influence factors and evolution level of information systems". Journal of Management Information System 12(4): 215-239.

Chomasatu, Y. 2014. "Faktor-faktor yang mempengaruhi performance of accounting information systems". Jurnal Paradigma 12(1): 71-75.

DeLone, W. H. 1988. "Determinants of success for computer usage in small business". MIS Quarterly (March): 51-61.

Doll, W. J., and G. Torkzadeh. 1988. "The measurement of end-eser computing satisfaction”. MIS Quarterly (June): 259-274.

Gibb, A. 1997. "Small firms training and competitiveness building upon the small business as a learning organization". International Small Business Journal 15(3): 13-29.

Handayani, R. 2007. “Analisis faktor-faktor yang mempengaruhi minat pemanfaatan sistem informasi dan penggunaan sistem informasi”. Jurnal Akuntansi dan Keuangan 9(2): 76-87.

Halimatusadiah, E., N. Nurhayati, and E. R. Rayandani. 2015. "Effects of top management support, education and training on the efectiveness of accounting information system (survey on Government-Owned Insurance Companies in Bandung)". International Journal of Managerial Studies and Research 3(10): 87-90.

Holmes, S., and D. Nicholls. 1988. "An analysis of the use of accounting by Australian small business". Journal of Small Business Management 26(2): 57-68.

Immelda, S. 2015. "Analisis faktor-faktor yang mempengaruhi kinerja sistem informasi akuntansi pada PT. DBTR Sidoarjo". Jurnal Universitas Nusantara PGRI Kediri.

Jen, T. F. 2002. "Faktor-faktor yang mempengaruhi kinerja sistem informasi akuntansi”. Jurnal Bisnis dan Akuntansi 4(2): 135-154.

Jogiyanto. 2005. Analisis dan desain sistem informasi. Yogyakarta: Penerbit Andi.

Kim, C., K. Suh, and J. Lee. 1998. "Utilization and user satisfaction in end-user computing: A task contingent model”. Information Resources Management Journal 11(4): 11-24.

Koeswoyo, F. 2006. "Faktor-faktor yang mempengaruhi kepuasan pemakai software akuntansi (studi empiris pada perusahaan pemakai software akuntansi K. 
System di pulau Jawa)". Tesis. Program Magister Sains Akuntansi Universitas Diponegoro Semarang.

Komara, A. 2005. "Analisis faktor-faktor yang mempengaruhi kinerja sistem informasi akuntansi”. Jurnal MAKSI 6(2): 143-160.

Puspitasari, I. 2007. "Analisis faktor-faktor yang mempengaruhi kinerja sistem informasi akuntansi pasar swalayan ADA Semarang”. Tesis. Program Magister Sains Akuntansi Universitas Diponegoro Semarang.

Respati, R. P., Sukirman, and N. Hamidi. 2013. "Faktor-faktor yang mempengaruhi kinerja sistem informasi akuntansi pada bank umum kota Surakarta". JUPE UNS 2(1): 119-130.

Rivaningrum, A. 2015. "Faktor-faktor yang mempengaruhi kinerja sistem informasi akuntansi pada Rumah Sakit Saras Husada Purworejo". Tesis. Universitas Negeri Semarang.

Romney, B. M., and J. P. Steinbart. 2006. "Accounting information systems". Tenth Edition. USA: Pearson Education, Inc. Upper Saddle River, New Jersey, 07458.

Soegiharto. 2001. "The influence's factors afectings of performances accounting information systems". Gajah Mada International Journal of Business 3(2): 3450

Srimindarti, C., and E. Puspitasari. 2012. "Kinerja sistem informasi akuntansi (SIA) ditinjau dari kepuasan pemakai dan pemakaian SIA yang dipengaruhi oleh partisipasi, pelatihan dan pendidikan pemakai SIA". Proceeding Call for Paper Pekan Ilmiah Dosen FEB-UKSW Salatiga: 517-530.

Widyaningrum, V. 2015. "Analisis faktor-faktor yang mempengaruhi kinerja sistem informasi akuntansi (SIA) (studi kasus PT. Sinarmas Distribusi Nusantara)". Tesis. Universitas PGRI Yogyakarta. 